\title{
The Volatility of Market Risk In Viet Nam Listed Public Utilities Company Groups during and after the Financial Crisis 2007-2009
}

\author{
Dinh Tran Ngoc Huy, PhD candidate \\ Banking University, HCMC - GSIM, International University of Japan, Japan \\ dtnhuy2010@gmail.com
}

\begin{abstract}
This study estimates market risk of total 45 listed companies in Viet Nam public utilities, natural gas and oil industry during the financial crisis period 2007-2009. Firstly, we found out in the research sample that there are $82 \%$ of firms, of total listed firms, with beta values lower than $(<) 1$, meaning with lower risk, and the systemic risk is acceptable. Secondly, there are $11 \%$ among total 45 listed firms, whose beta values higher than $(>)$ 1, meaning having stock returns fluctuating more than the market benchmark. Thirdly, among three (3) groups, the systemic risk in the electric power industry is the smallest, shown by estimated values of equity and asset beta mean, and asset beta variance in this industry is also the smallest. Finally, this paper generates some analytical outcomes that enable companies and government to have more evidence in establishing their policies in investments and in governance.
\end{abstract}

Keywords: equity beta, financial structure, financial crisis, risk, asset beta, public utility industry

JEL classification : G010, G100, G390

\section{Introduction}

During the global crisis 2007-2009, Viet Nam stock market has difficulties and opportunities. In this study, we perform a market risk analysis based on asset and equity beta of 228 listed companies in the three (3) groups of water, electric power, natural gas and oil firms. The three (3) above industries faced many difficulties in previous years such as how to increase the number of customers, service quality and revenues; now, they have to deal with some problems from the global crisis. From 2009-2011, the local government and central bank have performed some effective macro policies to help the economy to recover. After the previous published article on estimated beta for listed construction company groups, here, this paper emphasizes on analyzing un-diversifiable risk in the 3 above industries in one of emerging markets: Vietnam stock market during and after the financial crisis 2007-2009. There is no research, so far, done on the same topic.

The structure of this paper is as follow. The research issues and literature review will be mentioned in next sessions 2 and 3, for a short summary. Then, methodology and conceptual theories are introduced in session 4 and 5. Session 6 describes the data in empirical analysis. Session 7 presents empirical results and findings. Next, session 8 gives analysis of risk. Lastly, session 9 will conclude with some policy suggestions. This paper also provides readers with references, exhibits and relevant web sources.

\section{Research Issues}

In this research, we mention several issues on the estimating of beta for listed water, electric power, natural gas and oil companies in Viet Nam stock exchange as following: 
Hypothesis/Issue 1: Among the three (3) companies groups, under the financial crisis impact and high inflation, the beta or risk level of listed companies in gas and oil industries will relatively higher than those in the rest two (2) industries.

Hypothesis/Issue 2: Because Viet Nam is an emerging and immature financial market and the stock market still in the recovering stage, there will be a large disperse distribution in beta values estimated in the gas and oil industries.

Hypothesis/Issue 3: With the above reasons, the mean of equity and asset beta values of these listed gas and oil companies tend to impose a high risk level, i.e., beta should higher than $(>) 1$.

\section{Literature review}

William Sharpe., (1963) pointed in a simplified model of portfolio theory that each stock is correlated with each other stock because all are correlated with "the market", and stock return depends on some factors such as a constant alpha and stock beta.

And Harry Markowitz developed diversification and modern portfolio theory using beta as one of key factors. Beta is used in CAPM model, which is developed by Jack Treyner, John Lintner, Jan Mossin and William Sharpe.

Black, et al. (1972) tested whether portfolios consisting of stocks with high betas generate higher returns. Myron Scholes, Michael Jenson, and Fischer Black (1972) conducted a study showing that returns and beta relationship are flat or negatively correlated. Banz (1981) found out that smaller NYSE capitalization firms tend to have higher CAPM beta riskadjusted returns than larger firms. Next, Fama and French (1993) use CAPM beta, size and $\mathrm{BE} / \mathrm{ME}$ or book to market ratio to build a three- factor model that capture the various dimensions of risk.

Last but not least, Jiri Nova (2007) concludes that some CAPM beta is very useful in predicting stock returns.

\section{Conceptual theories}

Generally speaking, beta can be estimated for an individual firm by using regression.

Beta is used in CAPM model, and it is a risk measure of a listed firm compared to the overall market risk. For example, if beta of a single listed firm equals to 2,5 it means that the firm risk is 2,5 times riskier than the overall risk of the market. Therefore, when an investor wants to make an investment in a financial market, beta is an overall risk measure in investing in a stock exchange market.

Beta can be negative or equal to 0 in special cases. Beta $<0$ implies that the stock return moves in an opposite direction to the market benchmark. And beta equals to 0 means the stock return is uncorrelated with the movement of the market index. Asset is finance by debt and equity; so, beta can have 2 forms: equity and asset beta. Low beta stocks are supposed to have less risk but lower returns and vice versa. In short, knowing beta, people know the risk. In Viet Nam stock market, hardly we find out beta value higher than (>) 3.

\section{Methodology}

In order to estimate beta results, we use the input data from the live stock exchange market in Viet Nam during the four or five years of financial crisis 2007-2011. We select this period to do this research because Viet Nam stock market has shown the declining trend and this is the time highlighting financial crisis impacts.

Firstly, we use the market stock price of 45 listed companies in the public utilities (water and electric power), natural gas and oil industries in Viet Nam stock exchange market to calculate the variability in monthly stock price in the same period; secondly, we estimate the equity beta for these 3 listed groups of companies and make a comparative analysis. 
Thirdly, from the equity beta values of these listed companies, we perform a comparative analysis between equity and asset beta values of these 3 companies groups in Viet Nam. Finally, we use the results to suggest policy for both these enterprises, financial institutions and relevant organizations.

The below table gives us the number of public utilities, natural gas and oil firms used in the research of estimating beta:

\begin{tabular}{|c|c|c|c|c|}
\hline Market & $\begin{array}{c}\text { Listed Water } \\
\text { companies (1) }\end{array}$ & $\begin{array}{c}\text { Listed } \\
\text { Electric } \\
\text { power } \\
\text { companies (2) }\end{array}$ & $\begin{array}{c}\text { Listed Natural Gas } \\
\text { and Oil companies } \\
\text { (4) }\end{array}$ & Note (4) \\
\hline Viet Nam & 0 & 13 & 9 & $\begin{array}{l}\text { Estimating by } \\
\text { traditional } \\
\text { method }\end{array}$ \\
\cline { 2 - 5 } & 10 & 7 & 6 & $\begin{array}{l}\text { Estimating by } \\
\text { comparative } \\
\text { method }\end{array}$ \\
\hline Total & 10 & $\mathbf{2 0}$ & 15 & $\begin{array}{l}\text { Total firms in } \\
\text { group: 45 }\end{array}$ \\
\hline
\end{tabular}

(Note: The above data is at the December 12 $2^{\text {th }}, 2010$, from Viet Nam stock exchange)

\section{General Data Analysis}

Through the analysis of 45 firms in categories of industries: public utilities, natural gas and oil companies groups, the mean of equity beta is about 0,69 and that of asset beta is about 0,42 (lower). This shows us the effectiveness of using financial leverage to reduce the overall riskiness of the 3 industries. And these data are acceptable values during the crisis. While there is bigger difference in beta max values $(0,7)$, the difference in beta mean values is smaller (around 0,27).

In addition to, there is a difference in the sample variance of asset and equity beta values. The sample variance of asset beta is lower $(0,23)$, while that of equity beta is a little bit higher $(0,43)$, with a gap of 0,19 . This shows us, once again, that the effectiveness of using financial leverage has decreased the systemic risk for the whole industry.

Beside, max equity beta value is up to 2,8 that is a little bit high, compared to max asset beta value is 2,1 . The below table 2 shows us that a few companies still has larger risk exposure than most of the others.

And values of equity beta varies in a range from $-0,138(\mathrm{~min})$ to $2,883(\mathrm{max})$ and that of asset beta varies in a range from $-0,049(\mathrm{~min})$ to $2,176(\max )$. There are 3 listed company with beta lower than $(<) 0$ showing the stock return moving opposite to the market index (see table 2 below). Therefore, if beta of debt is assumed to be zero (0), the company's financial leverage contributes to a decrease in the market risk level.

Last but not least, there is a smaller difference between equity and asset beta variance values which is just 0,19 , compared to the relatively higher gap between average equity and average asset beta values, which is about 0,27 . So, there is not quite big effect from financial leverage on the gap between company's beta variance values.

Generally speaking, there is $73 \%$ of listed firms in 3 industries with acceptable beta values lower than $(<) 1$ and higher than $(>) 0$ whereas there is $20 \%$ of these listed firms having beta higher than $(>) 1$ and having more market risks. This number is somewhat high. And $73 \%$ of firms with acceptable beta values uses more financial leverage than the $20 \%$ (45\% compared to $36 \%)$. 
Table 1 - Estimating beta results for Four (4) Viet Nam Listed Public utilities, Natural gas and Oil Companies Groups (as of Dec 2012) (source: Viet Nam stock exchange data)

\begin{tabular}{|l|c|c|c|}
\hline Statistic results & Equity beta & $\begin{array}{c}\text { Asset beta (assume debt } \\
\text { beta }=0)\end{array}$ & Difference \\
\hline MAX & 2,883 & 2,176 & 0,7073 \\
\hline MIN & $-0,138$ & $-0,049$ & $-0,0887$ \\
\hline MEAN & 0,696 & 0,421 & 0,2745 \\
\hline VAR & 0,4316 & 0,2330 & 0,1986 \\
\hline \multicolumn{3}{|c|}{ Note: Sample size $: 45$} \\
\hline
\end{tabular}

Table 2 - The number of companies in research sample with different beta values and financial leverage

\begin{tabular}{|c|c|c|c|}
\hline Equity Beta & $\begin{array}{l}\text { No. of } \\
\text { firms }\end{array}$ & $\begin{array}{c}\text { Financial leverage } \\
\text { (average) }\end{array}$ & Ratio \\
\hline$<0$ & 3 & $64,20 \%$ & $7 \%$ \\
\hline $0<$ beta $<1$ & 33 & $45,58 \%$ & $73 \%$ \\
\hline Beta $>1$ & 9 & $36,08 \%$ & $20 \%$ \\
\hline total & 45 & $45,2 \%$ & $100 \%$ \\
\hline Asset Beta & $\begin{array}{l}\text { No. of } \\
\text { firms }\end{array}$ & $\begin{array}{c}\text { Financial leverage } \\
\text { (average) }\end{array}$ & Ratio \\
\hline$<0$ & 3 & $64,20 \%$ & $7 \%$ \\
\hline $0<$ beta $<1$ & 37 & $46,81 \%$ & $82 \%$ \\
\hline Beta $>1$ & 5 & $22,16 \%$ & $11 \%$ \\
\hline total & 45 & $45,2 \%$ & $100 \%$ \\
\hline
\end{tabular}

\section{Empirical Research Findings and Discussion}

\section{A- Water listed companies group}

During the crisis 2007-2009, the market for these companies still exists, but has certain difficulties. The rising inflation and rising lending interest rates and higher opportunity costs makes input materials or production costs increasing. So, the market for these firms has been affected because selling prices increase.

The table 3 below shows us the research of 10 listed firms in this category during the above period. In general, the mean of equity beta and asset beta are 0,900 and 0,714 , accordingly. These values are good numbers in term of indicating an acceptable undiversifiable risk.

Besides, the variance of equity and asset beta of the sample group equals to $\mathbf{0 , 8 5}$ and $\mathbf{0 , 6 2}$ accordingly which are higher than the variance of the entire sample equity and asset beta of $\mathbf{0 , 4 3}$ and $\mathbf{0 , 2 3}$. This is one characteristic of this industry.

We might note that equity beta value of 10 firms in this material category $(0,900)$ is the highest among those of firms in three (3) groups. This might be considered as another characteristic of these industries. Among three (3) industries, the systemic risk of water group companies is a bit higher than those of the rest groups. 
Table 3 - Estimating beta results for Viet Nam Listed Water Companies (as of Dec 2012) (source: Viet Nam stock exchange data)

\begin{tabular}{|c|c|c|c|c|c|}
\hline $\begin{array}{c}\text { Order } \\
\text { No. }\end{array}$ & $\begin{array}{c}\text { Company stock } \\
\text { code }\end{array}$ & Equity beta & $\begin{array}{l}\text { Asset beta (assume } \\
\text { debt beta }=0 \text { ) }\end{array}$ & Note & $\begin{array}{l}\text { Financial } \\
\text { leverage }\end{array}$ \\
\hline 1 & BTW & 2,272 & 1,951 & $\begin{array}{ll}\text { PJS } & \text { as } \\
\text { comparable }\end{array}$ & $14,1 \%$ \\
\hline 2 & BWA & 0,379 & 0,350 & $\begin{array}{ll}\text { LKW } & \text { as } \\
\text { comparable }\end{array}$ & $7,6 \%$ \\
\hline 3 & CLW & 0,452 & 0,293 & $\begin{array}{l}\text { NBW } \\
\text { comparable }\end{array}$ & $35,0 \%$ \\
\hline 4 & GDW & 1,723 & 1,210 & $\begin{array}{l}\text { BTW } \\
\text { comparable }\end{array}$ & $29,8 \%$ \\
\hline 5 & LKW & 0,402 & 0,345 & $\begin{array}{l}\text { NTW as } \\
\text { comparable }\end{array}$ & $14,3 \%$ \\
\hline 6 & NBW & 0,634 & 0,435 & $\begin{array}{ll}\text { SFC } & \text { as } \\
\text { comparable }\end{array}$ & $31,5 \%$ \\
\hline 7 & NNT & 0,090 & 0,014 & $\begin{array}{l}\text { PCG as } \\
\text { comparable }\end{array}$ & $84,0 \%$ \\
\hline 8 & NTW & 0,452 & 0,355 & $\begin{array}{l}\text { HFC as } \\
\text { comparable }\end{array}$ & $21,6 \%$ \\
\hline 9 & PJS & 2,552 & 2,176 & $\begin{array}{l}\text { VMG as } \\
\text { comparable }\end{array}$ & $14,7 \%$ \\
\hline 10 & TDW & 0,039 & 0,014 & $\begin{array}{ll}\text { NNT } & \text { as } \\
\text { comparable }\end{array}$ & $63,3 \%$ \\
\hline
\end{tabular}

Table 4 - Statistical results for Vietnam listed Water companies

\begin{tabular}{|l|c|c|c|}
\hline Statistic results & Equity beta & $\begin{array}{c}\text { Asset beta (assume debt } \\
\text { beta= 0) }\end{array}$ & Difference \\
\hline MAX & 2,552 & 2,176 & 0,3763 \\
\hline MIN & 0,039 & 0,014 & 0,0248 \\
\hline MEAN & 0,900 & 0,714 & 0,1853 \\
\hline VAR & 0,8532 & 0,6161 & 0,2371 \\
\hline \multicolumn{3}{|c|}{ Note: Sample size : 10} \\
\hline
\end{tabular}

\section{B- Electric power listed companies group}

In an emerging market such as Viet Nam, the market for electric power firms is definitely established and potential because of the public need for such necessary products and though it may be affected by impacts from the financial crisis. And this is the industry with the biggest sample size in this study.

The Table 5 below shows us the equity and asset beta mean of 20 listed electric power companies, with values of 0,489 and 0,305 , accordingly. This result, which means the risk is low and acceptable as the equity or asset beta value is the smallest. This partly, maintains the investor confidence of business operation of the whole industry and partly, indicates the good effect from using financial leverage.

Besides, the variance of beta values among these 6 firms is normal, from 0,28 to 0,24 for equity and asset beta, accordingly.

Please refer to Exhibit 2 for more information. 
Table 5 - Statistical results for Vietnam listed Electric power companies

\begin{tabular}{|l|c|c|c|}
\hline $\begin{array}{l}\text { Statistic } \\
\text { results }\end{array}$ & $\begin{array}{c}\text { Equity } \\
\text { beta }\end{array}$ & $\begin{array}{c}\text { Asset beta (assume debt } \\
\text { beta }=\mathbf{0})\end{array}$ & Difference \\
\hline MAX & 1,262 & 1,220 & 0,0425 \\
\hline MIN & $-0,138$ & $-0,029$ & $-0,1084$ \\
\hline MEAN & 0,489 & 0,305 & 0,1841 \\
\hline VAR & 0,1362 & 0,0936 & 0,0426 \\
\hline \multicolumn{3}{|c|}{ Note: Sample size : 20} \\
\hline
\end{tabular}

\section{C- Natural gas and Oil listed companies group}

Among 3 groups, this is the group with the medium number of listed firms (sample size $=15$ ) and with the medium equity beta var value of about 0,512 . Then, the asset beta mean of about 0,381 is a little higher than that of the electric power industry.

Different from firms in the electric power industry, 15 listed gas and oil firms has higher equity beta mean value and the higher equity beta var value, estimated at 0,835 and 0,512 , which implies there is a less concentration in market risks among firms in this industry. The equity and asset beta values are distributed in a wider range, from $-0,090$ to 2,883 , and from $-0,049$ to 1,444 , compared to those of electric power group, esp., and asset beta value is quite acceptable, indicating the effectiveness of using financial leverage.

Please refer to Exhibit 3 for more information.

Table 6 - Statistical results for Vietnam listed Natural gas and oil companies

\begin{tabular}{|l|c|c|c|}
\hline $\begin{array}{l}\text { Statistic } \\
\text { results }\end{array}$ & $\begin{array}{c}\text { Equity } \\
\text { beta }\end{array}$ & $\begin{array}{c}\text { Asset beta (assume } \\
\text { debt beta = 0) }\end{array}$ & Difference \\
\hline MAX & 2,883 & 1,444 & 1,4396 \\
\hline MIN & $-0,090$ & $-0,049$ & $-0,0406$ \\
\hline MEAN & 0,835 & 0,381 & 0,4543 \\
\hline VAR & 0,5117 & 0,1268 & 0,3849 \\
\hline \multicolumn{3}{|c|}{ Note: Sample size : 15} \\
\hline
\end{tabular}

\section{Comparison among 3 groups of public utilities, natural gas and oil companies}

In the below chart, we can see among the 3 groups, equity beta value of the electric power group is the lowest $(0,489)$ and asset beta value of this group is the lowest $(0,305)$. Assuming debt beta is 0 , financial leverage has helped many listed firms in these industries lower the un-diversifiable risk.

Additionally, we see the asset beta mean values of three groups have certain difference and acceptable.

Next, we can recognize from the chart that, the risk and its dispersion in the electric power industry lower than that in the rest industries.

Last but not least, from the calculated results, variance of asset beta in the natural gas and oil industries are low while that of water industry is much higher. 
Chart 1 - Statistical results of three (3) groups of 45 listed VN public utilities, natural gas and oil firms during/after the crisis period 2007-2009

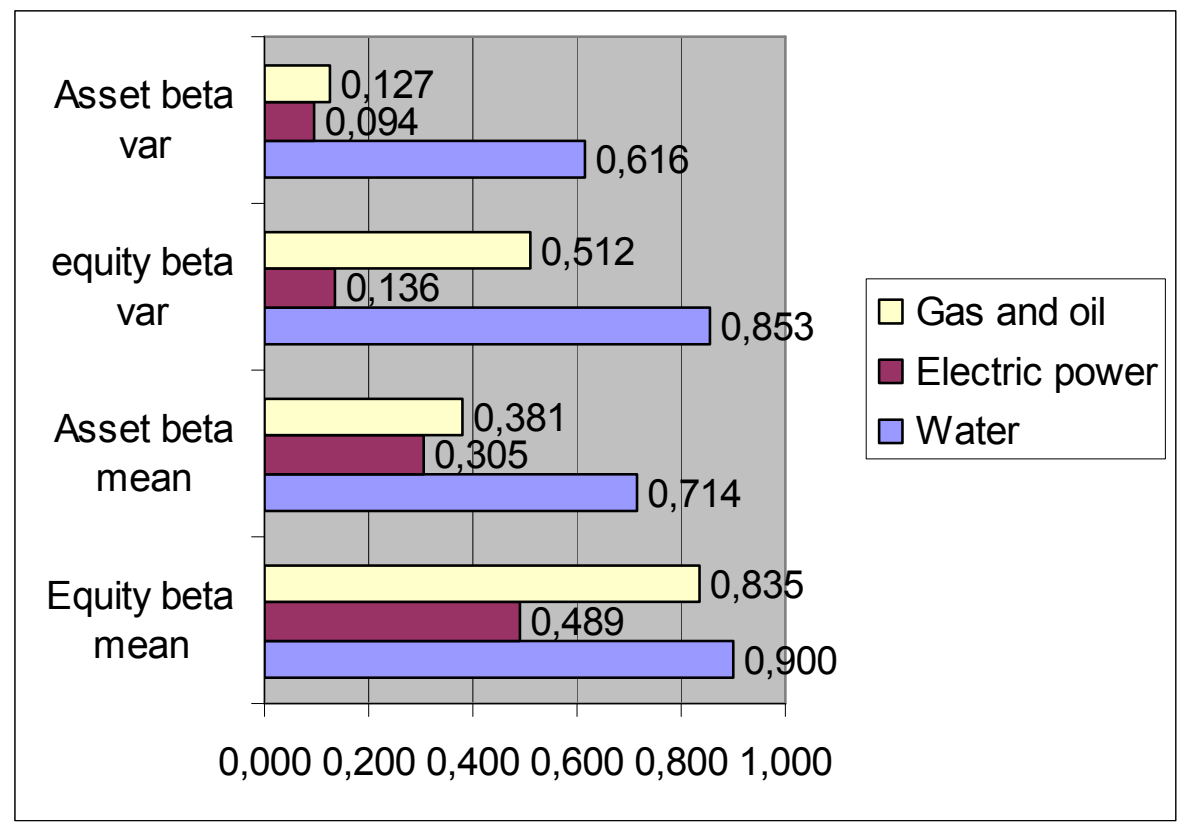

Chart 2 - Statistical results of three (3) groups of 45 listed VN public utilities, natural gas and oil firms during/after the crisis period 2007-2011

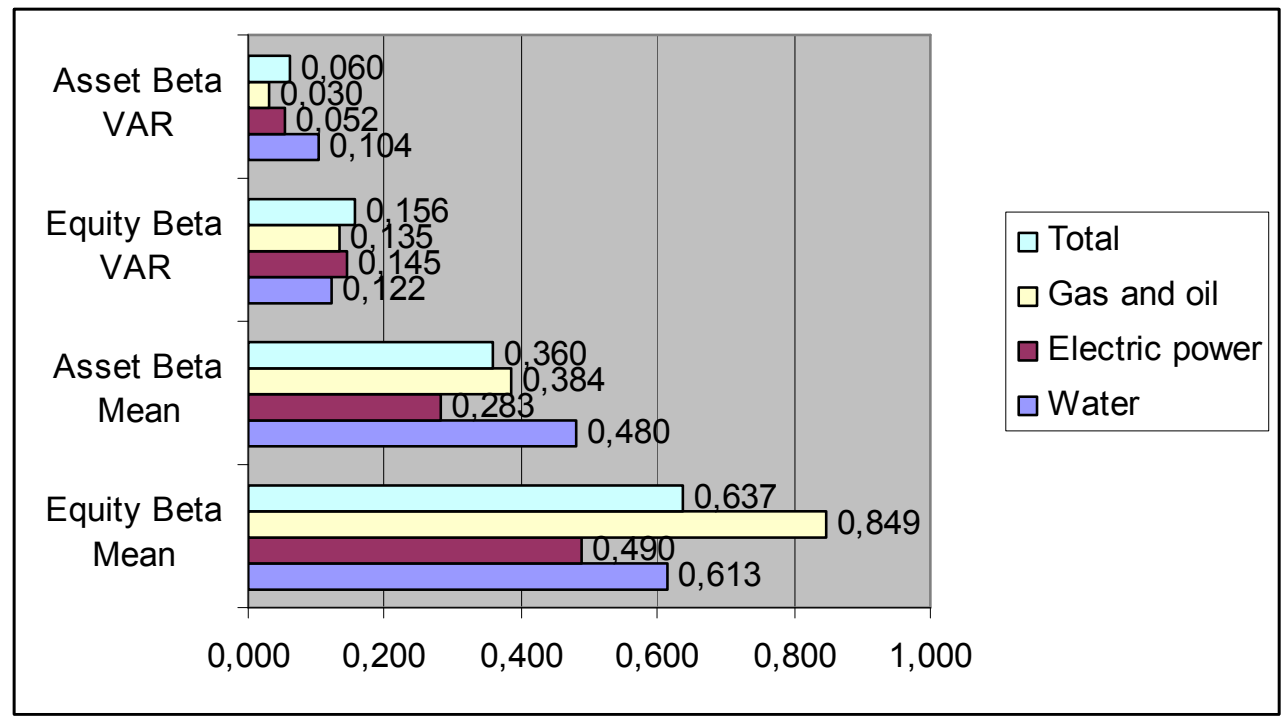

(source: Viet Nam stock exchange 2012)

\section{Empirical results}

In electric power industry, asset beta mean reach the lowest value $(0,305)$ and asset beta var reaches minimum $(0,094)$, compared to the rest 2 cases.

In water industry, asset beta mean reach the highest value $(0,714)$ whereas asset beta var reaches maximum $(0,616)$, compared to the rest 2 cases.

And finally, in gas and oil industry, equity beta mean reaches medium value $(0,835)$ while asset beta var reaches the $2^{\text {nd }}$ lowest value $(0,127)$, compared to the rest 2 cases.

\section{Risk analysis}

In short, the more debt the firm uses, the more risk it takes. Beside, the increasing interest on loans might drive the earning per share (EPS) lower. 
On the other hand, in the case of increasing leverage, the company will expect to get more returns. The financial leverage becomes worthwhile if the cost of additional financial leverage is lower than the additional earnings before taxes and interests (EBIT). FL has become a positive factor linking finance and growth in many companies. Beside, leverage choice could also become a determinant of firms' capital structure and financial risk.

\section{Discussion}

Looking at exhibit 4 , it is noted that comparing to beta result of telecomm. industry in the period 2007-2011, asset beta mean of gas and oil industry group $(0,381)$ during 2009-2011 is lower. And the risk dispersion in gas and oil industry during 2009-2011 (shown by asset beta var of 0,127 ) is also lower.

\section{Conclusion and Policy suggestion}

In general, the government has to consider the impacts on the mobility of capital in the markets when it changes the macro policies. Beside, it continues to increase the effectiveness of building the legal system and regulation supporting the plan of developing public utilities, natural gas and oil market. The Ministry of Finance continues to increase the effectiveness of fiscal policies and tax policies which are needed to combine with other macro policies at the same time. The State Bank of Viet Nam continues to increase the effectiveness of capital providing channels for public utilities, natural gas and oil companies as we could note that in this study when using leverage, the risk level decreases $(<0,8)$ much as well as the asset beta $\operatorname{var}(<0,7)$.

Furthermore, the entire efforts among many different government bodies need to be coordinated.

Finally, this paper suggests implications for further research and policy suggestion for the Viet Nam government and relevant organizations, economists and investors from current market conditions. 


\section{References}

1. Alcock J., Baum A., Colley N. and Steiner E. (2013), The Role of Financial Leverage in the Performance of Private Equity Real Estate Funds, SSRN Working Paper.

2. Bancel F. and Mittoo, U.R. (2011), Financial Flexibility and The Impact of The Global Financial Crisis : Evidence from France, International Journal of Managerial Finance

3. Beyhaghi M. and Hawley, J.P. (2012), Modern Portfolio Theory and Risk Management: Assumptions and Unintended Consequences, Journal of Sustainable Finance \& Investment

4. Bijlsma M.J., Boone J. and Zwart G. (2012), Competition for Traders and Risk, CEPR Discussion Paper No.DP8816.

5. Chen R.R, Chidambaran N.K., Imerman M.B. and Sopranzetti B.J. (2013), Liquidity, Leverage, and Lehman: A Structural Analysis of Financial Institutions in Crisis, Fordham School of Business Research Paper No.2279686.

6. Dimitrov V. and Jain P.C. (2006), The Value Relevance of Changes in Financial Leverage, SSRN Working Paper.

7. Eugene, F.F. and French K.R. (2004), The Capital Asset Pricing Model: Theory and Evidence, Journal of Economic Perspectives

8. Gunaratha V. (2013), The Degree of Financial Leverage as a Determinant of Financial Risk: An Empirical Study of Colombo Stock Exchange in Sri Lanka, 2nd International Conference on Management and Economics Paper.

9. Grullon G., Lyandres E. and Zhdanov A. (2012), Real Options, Volatility and Stock Returns, Journal of Finance

10. Huy, D.T.N., (2012), Estimating Beta of Viet Nam listed construction companies groups during the crisis, Journal of Integration and Development

11. Fan J.P.H., Wei J.K.C. and Xu X. (2009), Corporate Finance and Governance in Emerging Markets: A Selective Review and An Agenda for Future Research, Journal of Corporate Finance

12. Kalimipalli M. and Athanassakos G. (2003), Analyst Forecast Dispersion and Future Stock Return Volatility, Quarterly Journal of Business and Economics

13. Lettau M., Ludvigson S.C. and Wachter, J.A.(2008), The Declining Equity Premium: What Role Does Macroeconomic Risk Play, The Review of Financial Studies

14. Maia M.V. (2010), Cash-Flow Risks, Financial Leverage and the Cross Section of Equity Returns, SSRN Working Paper.

Other web sources

15. http://www.mofa.gov.vn/vi/

16. http://www.hsx.vn/hsx/

17. www.tuoitre.com.vn;

18. www.saigontimes.com.vn;

19. www.mof.gov.vn;

20. www.vneconomy.com.vn; 
Exhibit 1 - Interest rates, Inflation, GDP growth and macroeconomics factors (source: Viet Nam commercial banks and economic statistical bureau)

\begin{tabular}{|c|c|c|c|c|c|c|}
\hline Year & $\begin{array}{l}\text { Basic } \\
\text { rates }\end{array}$ & $\begin{array}{l}\text { Lending } \\
\text { rates }\end{array}$ & $\begin{array}{l}\text { Deposit } \\
\text { rates }\end{array}$ & Inflation & GDP & $\begin{array}{l}\text { USD/VND } \\
\text { rate }\end{array}$ \\
\hline 2012 & $\mathrm{n} / \mathrm{a}$ & $\begin{array}{l}12 \% \\
15 \%\end{array}$ & $9 \%$ & $6,81 \%$ & $5,03 \%$ & 20.828 \\
\hline 2011 & $9 \%$ & $\begin{array}{l}18 \%- \\
22 \%\end{array}$ & $\begin{array}{l}13 \%- \\
14 \%\end{array}$ & $18 \%$ & $5,89 \%$ & 20.670 \\
\hline 2010 & $8 \%-9 \%$ & $\begin{array}{l}19 \%- \\
20 \%\end{array}$ & $\begin{array}{l}13 \%- \\
14 \%\end{array}$ & $\begin{array}{l}11,75 \% \\
\text { (Estimated } \\
\text { at Dec } \\
2010)\end{array}$ & $\begin{array}{l}6,5 \% \\
\text { (expected) }\end{array}$ & 19.495 \\
\hline 2009 & $7 \%$ & $\begin{array}{l}9 \%- \\
12 \%\end{array}$ & $\begin{array}{l}9 \%- \\
10 \%\end{array}$ & $6,88 \%$ & $5,2 \%$ & 17.000 \\
\hline 2008 & $\begin{array}{l}8,75 \%- \\
14 \%\end{array}$ & $\begin{array}{l}19 \%- \\
21 \%\end{array}$ & $\begin{array}{l}15 \%- \\
16,5 \%\end{array}$ & $22 \%$ & $6,23 \%$ & 17.700 \\
\hline 2007 & $8,25 \%$ & $\begin{array}{l}12 \%- \\
15 \%\end{array}$ & $\begin{array}{l}9 \%- \\
91 \%\end{array}$ & $12,63 \%$ & $8,44 \%$ & 16.132 \\
\hline 2006 & $8,25 \%$ & & & $6,6 \%$ & $8,17 \%$ & \\
\hline 2005 & $7,8 \%$ & & & $8,4 \%$ & & \\
\hline Note & \multicolumn{6}{|c|}{$\begin{array}{l}\text { Approximately (2007: required reserves ratio at SBV is changed } \\
\text { from } 5 \% \text { to } 10 \%) \\
\qquad(2009 \text { : special supporting interest rate is } 4 \%)\end{array}$} \\
\hline
\end{tabular}

Exhibit 2 - Estimating beta results for Viet Nam Listed Electric power Companies (as of Dec 2012) (source: Viet Nam stock exchange data)

\begin{tabular}{|c|c|c|c|c|c|}
\hline $\begin{array}{l}\text { Order } \\
\text { No. }\end{array}$ & $\begin{array}{c}\text { Compan } \\
\text { y stock } \\
\text { code } \\
\end{array}$ & $\begin{array}{l}\text { Equity } \\
\text { beta }\end{array}$ & $\begin{array}{c}\text { Asset beta (assume debt } \\
\text { beta }=0 \text { ) }\end{array}$ & Note & $\begin{array}{c}\text { Financia } \\
1 \\
\text { leverage }\end{array}$ \\
\hline 1 & BTP & 0,720 & 0,306 & & $57,5 \%$ \\
\hline 2 & CHP & 0,349 & 0,144 & 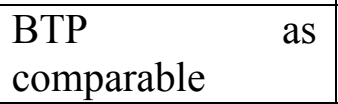 & $58,7 \%$ \\
\hline 3 & DNC & $-0,052$ & $-0,016$ & & $68,8 \%$ \\
\hline 4 & DRL & 0,458 & 0,376 & $\begin{array}{l}\text { NLC as } \\
\text { comparable }\end{array}$ & $17,9 \%$ \\
\hline 5 & DTV & 0,511 & 0,483 & $\begin{array}{ll}\text { NLC } \\
\text { comparable }\end{array}$ & $5,4 \%$ \\
\hline 6 & GHC & 0,496 & 0,162 & $\begin{array}{ll}\text { NBP } \\
\text { comparable }\end{array}$ & $67,3 \%$ \\
\hline 7 & HJS & 0,407 & 0,117 & & $71,3 \%$ \\
\hline 8 & KHP & 0,967 & 0,484 & & $50,0 \%$ \\
\hline 9 & NBP & 1,262 & 0,835 & & $33,9 \%$ \\
\hline 10 & ND2 & 0,165 & 0,039 & $\begin{array}{l}\text { TBC as } \\
\text { comparable }\end{array}$ & $76,2 \%$ \\
\hline 11 & NLC & 0,532 & 0,494 & & $7,2 \%$ \\
\hline 12 & NT2 & $-0,138$ & $-0,029$ & & $78,6 \%$ \\
\hline 13 & PPC & 0,792 & 0,227 & & $71,3 \%$ \\
\hline
\end{tabular}




\begin{tabular}{|r|l|l|l|lr|}
14 & RHC & 0,270 & 0,149 & & $44,7 \%$ \\
\hline 15 & SBA & 0,146 & 0,052 & $\begin{array}{l}\text { SJD } \\
\text { comparable }\end{array}$ & as \\
\hline 16 & SEB & 0,331 & 0,151 & & $54,8 \%$ \\
\hline 17 & SHP & 0,415 & 0,210 & $\begin{array}{l}\text { BTP } \\
\text { comparable }\end{array}$ & as \\
\hline 18 & SJD & 0,348 & 0,183 & & $49,4 \%$ \\
\hline 19 & TBC & 0,563 & 0,522 & & $47,4 \%$ \\
\hline 20 & TIC & 1,247 & 1,220 & & $7,3 \%$ \\
\hline
\end{tabular}

Exhibit 3 - Estimating beta results for Viet Nam Listed Natural gas and oil Companies (as of Dec 2012) (source: Viet Nam stock exchange data)

\begin{tabular}{|c|c|c|c|c|c|}
\hline $\begin{array}{l}\text { Order } \\
\text { No. }\end{array}$ & $\begin{array}{c}\text { Company } \\
\text { stock } \\
\text { code }\end{array}$ & $\begin{array}{c}\text { Equity } \\
\text { beta }\end{array}$ & $\begin{array}{c}\text { Asset beta } \\
\text { (assume } \\
\text { debt beta }= \\
\text { 0) }\end{array}$ & Note & $\begin{array}{l}\text { Financial } \\
\text { leverage }\end{array}$ \\
\hline 1 & ASP & 0,496 & 0,119 & $\begin{array}{l}\text { PGC as } \\
\text { comparable }\end{array}$ & $76,0 \%$ \\
\hline 2 & $\mathrm{CNG}$ & 0,147 & 0,086 & $\begin{array}{l}\text { ASP as } \\
\text { comparable }\end{array}$ & $41,7 \%$ \\
\hline 3 & GAS & $-0,090$ & $-0,049$ & $\begin{array}{l}\text { NT2 as } \\
\text { comparable }\end{array}$ & $45,2 \%$ \\
\hline 4 & HFC & 0,546 & 0,351 & & $35,7 \%$ \\
\hline 5 & HTC & 0,546 & 0,225 & $\begin{array}{l}\text { MTG as } \\
\text { comparable }\end{array}$ & $58,7 \%$ \\
\hline 6 & MTG & 0,773 & 0,387 & & $49,9 \%$ \\
\hline 7 & PCG & 0,443 & 0,278 & $\begin{array}{l}\text { MTG as } \\
\text { comparable }\end{array}$ & $37,1 \%$ \\
\hline 8 & PGC & 0,869 & 0,418 & & $51,9 \%$ \\
\hline 9 & PGD & 1,171 & 0,691 & & $41,0 \%$ \\
\hline 10 & PTH & 0,359 & 0,146 & $\begin{array}{l}\text { HFC as } \\
\text { comparable }\end{array}$ & $59,3 \%$ \\
\hline 11 & SFC & 0,853 & 0,650 & & $23,8 \%$ \\
\hline 12 & TMC & 0,777 & 0,296 & & $61,8 \%$ \\
\hline 13 & VMG & 2,883 & 1,444 & & $49,9 \%$ \\
\hline 14 & PGS & 1,013 & 0,207 & & $79,5 \%$ \\
\hline 15 & PVG & 1,743 & 0,465 & & $73,3 \%$ \\
\hline
\end{tabular}


Exhibit 4 - Statistical results of four (4) groups of 64 listed VN computer and electrical firms during/after the crisis period 2007-2011

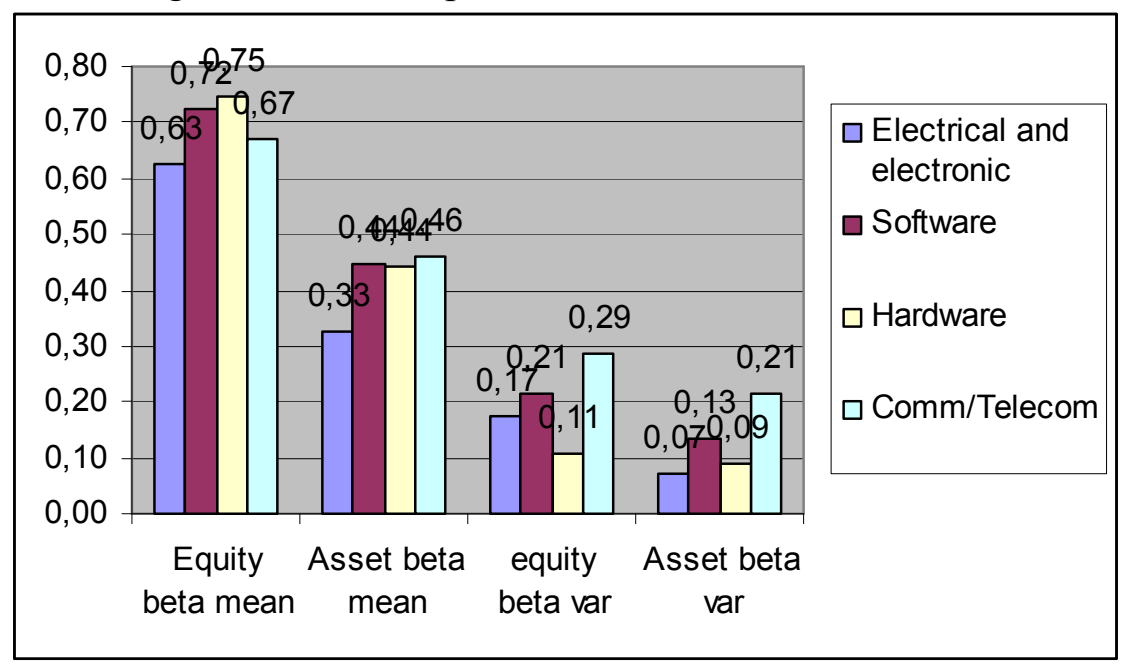

Exhibit 5 - Statistical results of three (3) groups of 103 listed construction firms during crisis period

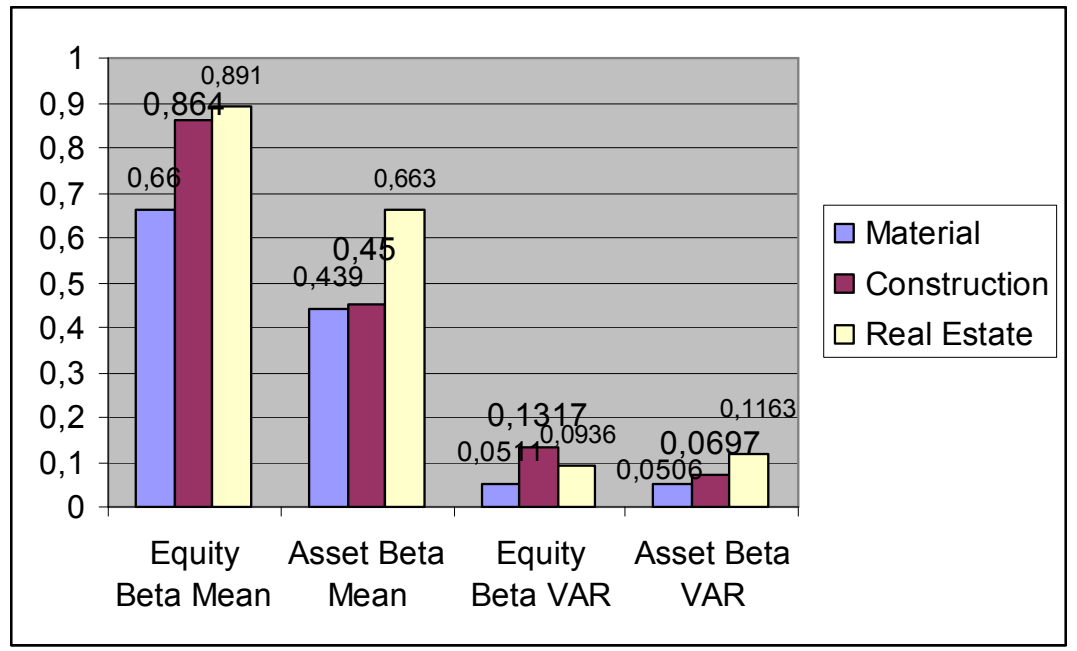

(source: Viet Nam stock exchange 2012)

Exhibit 6- VNI Index and other stock market index during crisis 2006-2010

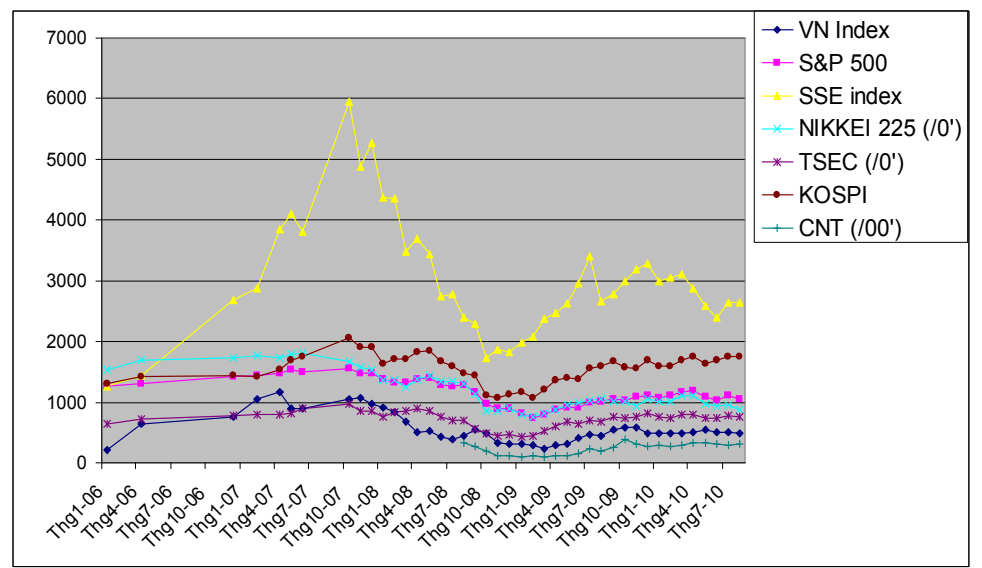

Author note: My sincere thanks are for the editorial office and Lecturers/Doctors at Banking University and International University of Japan, Arhus Biz School, \& Amos Tuck School of Biz. Through the qualitative analysis, please kindly email me if any error found. 